\title{
PUSAT LAYANAN INTEGRATIF LANSIA DI MASYARAKAT (SENIOR CENTER)
}

\author{
Sri Sunarti ${ }^{1}$ Rahmad Ramadhan ${ }^{1}$ \\ ${ }^{1}$ Departemen Ilmu Penyakit Dalam, Fakultas Kedokteran Universitas Brawijaya, Malang \\ Indonesia \\ Emai : sinartitran@rocketmail.com;sri_sunarti.fk@ub.ac.id
}

\begin{abstract}
ABSTRAK
Senior center adalah salah satu contoh tempat bertemunya para lansia (orang lanjut usia) di masyarakat, sehingga kebutuhan mereka untuk bersosialisasi, beraktifitas secara fisik, kebutuhan emosional dan kecerdasan mereka bisa tetap terasah. Programprogram tersebut khusus didesain sesuai kebutuhan untuk memberikan hasil yang positif kepada para lansia, meski dengan keterbatasan fisik, kognitif, dan masalah sosial lainnya. Senior center dianggap merupakan wahana yang penting untuk mempertahankan kemandirian para lansia di masyarakat.
\end{abstract}

Kata Kunci: Pusat layanan integratif, lansia

\section{ABSTRACT}

A senior center is a type of community center where older adults can congregate to fulfill many of their social, physical, emotional, and intellectual needs. These program is designed to have a positive impact on various condition of elderly, including physically frail, or cognitively impaired individuals, in accordance with the care plan developed for each participant. The senior center claimed as an important vebicle for enbancing independent living for older adults.

Keywords: Senior Center, elderly, geriatric

\section{PENDAHULUAN}

Keberhasilan pembangunan kesehatan di Indonesia berdampak terhadap terjadinya penurunan angka kelahiran, angka kesakitan, dan angka kematian serta peningkatan Umur Harapan Hidup (UHH) saat lahir. Meningkatnya UHH diproyeksikan akan terus bertambah, mengakibatkan peningkatan jumlah penduduk lanjut usia secara signifikan di masa yang akan datang (Hermana, 2010).

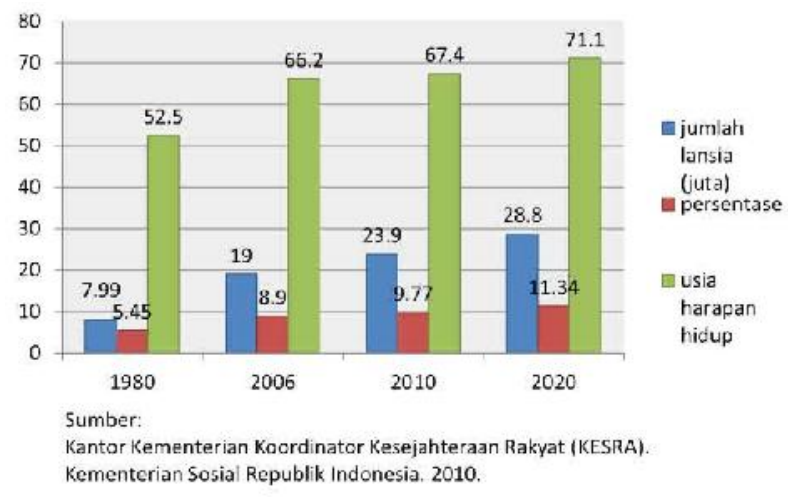

Gambar 1. Grafik Perkembangan Penduduk Lanjut usia (lansia) di Indonesia
Dengan bertambahnya usia, fungsi fisiologis mengalami penurunan akibat proses degeneratif (penuaan), sehingga penyakit tidak menular banyak muncul pada lanjut usia. Angka kesakitan (morbidity rates) lanjut usia adalah proporsi penduduk lanjut usia yang mengalami masalah kesehatan hingga mengganggu aktivitas sehari-hari selama satu bulan terakhir. Bila dilihat perkembangannya dari tahun 2005-2014, derajat kesehatan penduduk lanjut usia mengalami peningkatan yang ditandai dengan menurunnya angka kesakitan pada lanjut usia (Hermana, 2010).

Masalah utama bagi para lanjut usia adalah pemenuhan kebutuhan pelayanan kesehatan, oleh karena itu perlu dikembangkan pelayanan kesehatan yang lebih mengutamakan upaya peningkatan, pencegahan, dan pemeliharaan kesehatan disamping upaya penyembuhan dan pemulihan (Haryanto JT, 2015). 


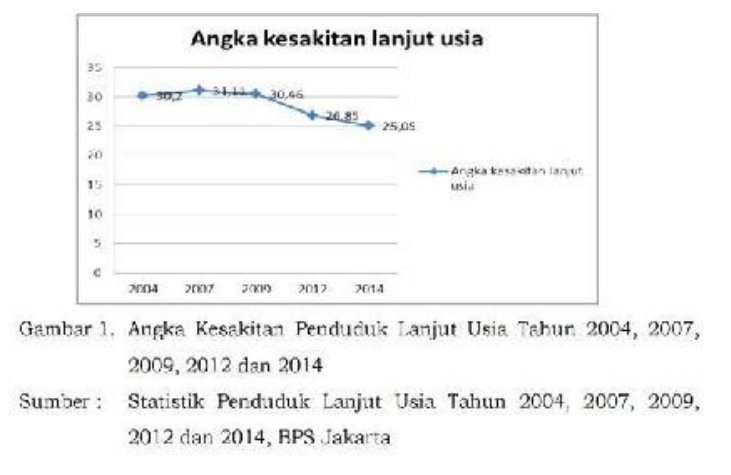

Gambar 2. Grafik Angka Kesakitan Lanjut Usia

Program pembinaan kesehatan lanjut usia telah dikembangkan sejak tahun 1986, sedangkan pelayanan geriatri di rumah sakit mulai dikembangkan sejak tahun 1988 oleh Rumah Sakit Umum Pusat Dr. Cipto Mangunkusumo dan Rumah Sakit Dr. Kariadi di Semarang Jawa Tengah. Pada tahun 2000 Kementerian Kesehatan mulai mengembangkan konsep pelayanan kesehatan santun lanjut usia yang diawali dengan rencana pengembangan Pusat Kesehatan Masyarakat (Puskesmas) yang menyelenggarakan pelayanan kesehatan santun lanjut usia di seluruh Indonesia melalui wadah Kelompok Usia Lanjut (Poksila) (Harjanto, JT,2015) dan disusul dengan terbitnya Permenkes no 67/2015 tentang Penyelenggaraan Pelayanan Geriatri di Puskesmas.Pada tahun 2014 terbit Permenkes no 79 tentang Penyelenggaraan Pelayanan Geriatri di Rumah Sakit untuk membuat aturan standar untuk pelayanan lansia di Rumah Sakit, disusul oleh Permenkes no 25/2016 tentang Rencana Aksi Nasional Kesehatan Lanjut Usia Tahun 2016-2019 yang mengatur peran Pemerintah Pusat dan Daerah serta lintas sektor dan masyarakat dalam salah satu misinya untuk meningkatkan pemberdayaan lanjut usia, keluarga, dan masyarakat untuk mewujudkan lanjut usia yang sehat, mandiri, aktif dan produktif selama mungkin.

Kesadaran diri (self-awareness) adalah kunci untuk kualitas hidup seseorang secara keseluruhan dan kepuasan diri. Banyak kegiatan sosial dapat digunakan untuk membantu meningkatkan kesadaran diri individu. Oleh karena itu, dukungan sosial bagi orang lanjut usia sangatlah penting. Hal itu dapat diwujudkan salah satunya melalui wadah pelayanan dan aktivitas secara berkelompok, bersama-sama melalui Senior Center.

Tujuan Penulisan ini adalah memberikan pengetahuan tentang apa itu Senior Center.

\section{METODE}

Studi pustaka berikut menggunakan beberapa referensi dengan menggabungkan beberapa praktik baik yang telah dilakukan oleh berbagai pusat layanan lansia di komunitas.

\section{DISKUSI}

Senior Center: Grand Design

Kebanyakan orang tidak akan memilih kesepian, kesendirian serta rasa terisolasi, dibandingkan menghabiskan waktu dengan sahabat. Namun, ternyata kurangnya dukungan sosial benarbenar menghambat kualitas keseluruhan hidup seorang lanjut usia (Hannon K, 2015).

Kurangnya dukungan sosial terkait dengan dampak negatif pada kesehatan dan kesejahteraan, terutama untuk orang tua. Dukungan dari orang lain bisa menjadi penting dalam mengurangi stres, meningkatkan kesehatan fisik dan mengalahkan masalah psikologis seperti depresi dan kecemasan (Kristina, 2009).

Ketika mempertimbangkan yang memberikan dukungan sosial bagi individu lanjut usia, maka yang menjadi peran utama adalah anggota keluarga. Meskipun benar bahwa sebagian besar dukungan yang datang dari anggota keluarga, ada banyak situasi di mana anggota keluarga tidak dapat mendukung.

Beberapa hal yang menyebabkan dukungan keluarga atau sosial kepada lansia dalam keluarga tidak optimal adalah karena :

- stres karena tanggung jawab,

- penyakit,

- kematian,

- masalah keuangan,

- pekerjaan relokasi,

- Pekerjaan anak,

- Kesibukan anak mengasuh cucu dari seorang lanjut usia.

Layanan berbasis komunitas dapat sangat berguna bagi individu lanjut usia. Layanan untuk orang yang lebih tua dapat mencakup banyak bidang, tapi salah satu hal yang paling penting seperti yang dibahas sebelumnya adalah dukungan sosial. Dukungan bagi orang tua dapat ditemukan di banyak tempat termasuk di :(Kristina, 2009, Sarosy L, 2009, Patton C, 2012, Elizabeth B, 2013) 
senior centers, assisted living facilities, meal delivery, religious affiliations, adult day care centers, dll
Namun, dukungan sosial harus mencakup lebih dari kehadiran fisik atau percakapan. Penelitian telah menunjukkan bahwa layanan dukungan sosial harus berisi kegiatan berkualitas (Kristina, 2009, Sarosy L, 2009).

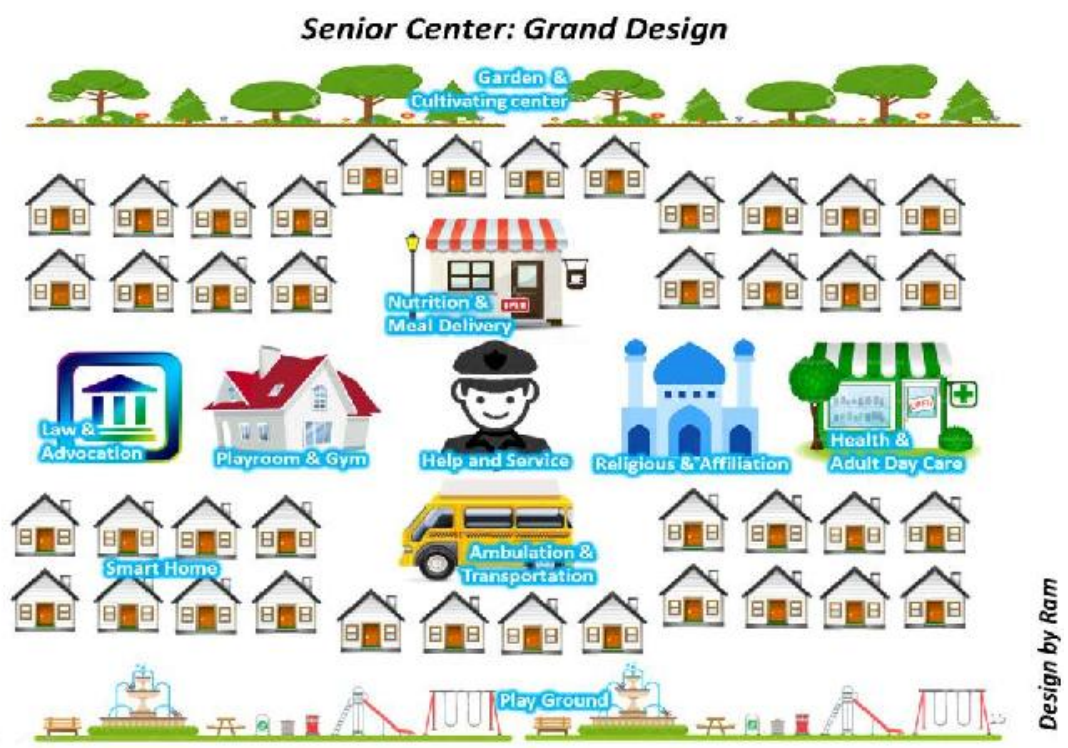

Gambar 3. Senior Center: Grand Design

Kegiatan dan Fasilitas pada Senior Center (Hannon K, 2015,Kristina, 2009, Sarosy L, 2009, Elizabeth B,2013) bisa berupa :

- menulis jurnal,

- pembacaan dan cerita buku favorit,

- latihan kelompok,

- kelompok bernyanyi,

- program kesehatan (termasuk Zumba dan Yoga),

- seni / kegiatan humaniora,

- program antargenerasi,

National Council on the Aging (NCOA) Amerika, memberikan keterangan terkait Senior Center: "Senior Centers are designated as community focal points through the Older Americans Act. The National Institute of Senior Centers defines a senior center as a place where older adults come together for services and activities that reflect their experience and skills, respond to their diverse needs and interests, enhance their dignity, support their independence, and encourage their involvementin and with the center and the community. 'Dari keterangan tersebut, didapatkan bahwa pentingnya komunitas untuk bersosial dan berinteraksi diantara orang lanjut usia.

Pemerintah pusat dan daerah juga memikul tanggung jawab untuk mempromosikan dan memberi dukungan terhadap "senior center" untuk meningkatkan kualitas hidup bagi warga negara lanjutusia. Advokasi kepada masyarakat serta promosi kesehatan sangatlah penting sebagai upaya pencegahan (preventive) terhadap penyakit.(Jacobson, 2016).

Health and Adult Day Care(Sarosy L, 2009).

Acute care

- Pelayanan kesehatan sekunder di mana pasien menerima pengobatan jangka pendek aktif tetapi untuk cedera parah atau episode penyakit, kondisi medis yang mendesak, atau selama pemulihan dari operasi.

- Contoh: trauma, kasus indikasi operasi cito, sindrom koroner akut 


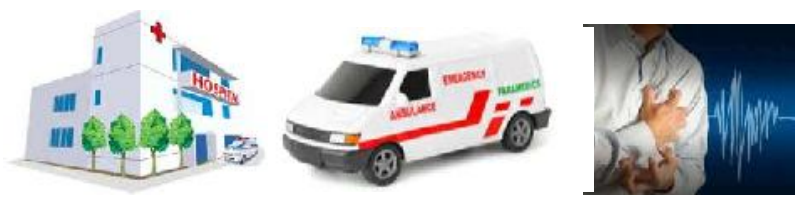

Gambar 4. Acute care pada Senior Center Chronic care

- Perawatan kronis mengacu pada perawatan medis terhadap penyakit jangka panjang

- Contoh: asma, diabetes, emfisema, bronkitis kronik, penyakit jantung kongestif, sirosis hati, hipertensi dan depresi.

- Edukasi pentingnya pengobatan dan motivasi keteraturan minum obat

Tanpa pengobatan yang efektif kondisi kronis dapat menyebabkan kecacatan.
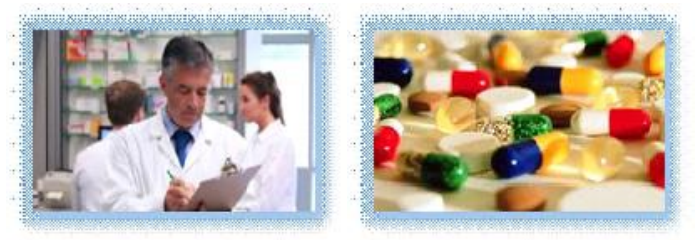

Gambar 5. Contoh Chronic care pada Senior Center berupa layanan edukasi obat

\section{Home care}

- Sarana bagi orang-orang yang membutuhkan perawatan terus menerus dan mengalami kesulitan yang signifikan mengatasi kegiatan yang diperlukan sehari-hari.

- Menyediakan tenaga dokter, perawat, tim medis lain dalam membantu pelayanan kesehatan di rumah

- Perawatan dan rehabilitasi

- Pemenuhan rasio 1 caregiver : 6-8 pasien

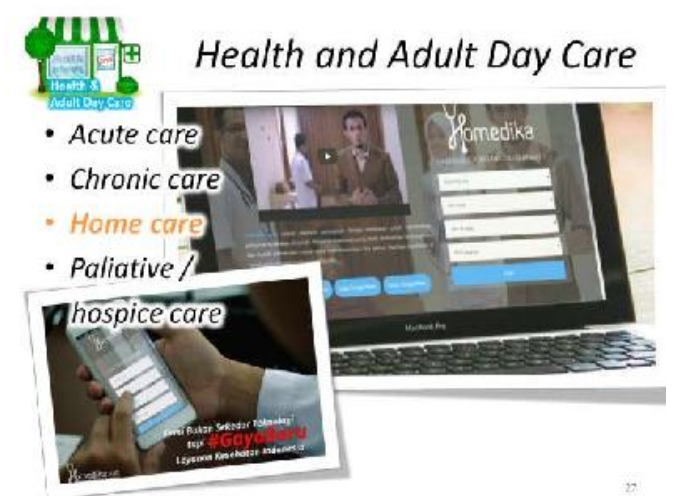

Gambar 6. Contoh Layanan Home Care berbasis online
Paliative / hospice care

- Tujuan dari perawatan paliatif adalah untuk membantu orang-orang dengan penyakit terminal atau tahap akhir/ end-stage.

- Perawatan paliatif juga membantu mengatasi masalah emosional, sosial, praktis, dan spiritual dan meningkatkan kualitas hidup.

- Contoh: kanker, komplikasi dari penyakit kardiovaskuler-ginjal-liver, dementia, HIV/AIDS, dll.

Nutritional and Meal Delivery (Sarosy L, 2009).

Problematika nutrisi lanjut usia, meliputi:

- Kebutuhan kalori menurun

- Pemenuhan zat gizi cukup

- Selera makan berkurang

- Kemampuan mengunyah berkurang

- Kemampuan adsorbsi nutrien berkurang

- Food moodswing

Bahan makanan, nutrien, dan micronutrien

Bahan makanan, nutrien, dan micronutrien yang dibutuhkan pada lanjut usia:

- Vitamin B12

B12 diperlukan untuk bahan pembentukan eritrosit, DNA, dan menjaga fungsi saraf.

- Folate/ Folic A cid

Kekurangan essensial dapat menyebabkan anemia.

- Calcium

Calcium bagian dari elektrolit tubuh yang diperlukan, membentuk dan menjaga kekuatan tulang.

- Vitamin D

"Vitamin D membantu adsorbsi calcium, menjaga densitas / kepadatan tulang, dan mencegah osteoporosis.

- Potassium (kalium)

K alium juga diperlukan untuk menjaga ketahanan tulang. Mineral essensial ini mempunyai funsi vital bagi fungsi sel.

Strategi problematika nutrisi lanjut usia (Sarosy L, 2009).

- Cooking class bersama komunitas usia lanjut

- Melibatkan usia lanjut untuk membuat menu yang diinginkan

- Nutrisionist untuk membantu kalkulasi kebutuhan nutrisi

- Layanan antar diet bagi warga berkebutuhan nutrisi khusus 
Religious and Affiliation

- Bersikap baik kepada orang tua

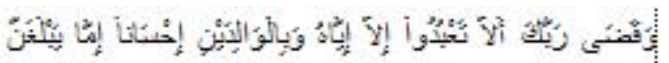

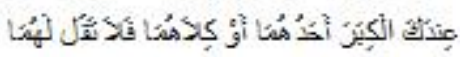

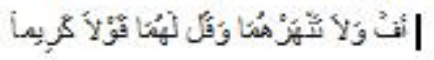

'Dan Tubanmu telab memerintabkan supaya kamu jangan menyembah selain Dia dan hendaklah kamu berbuat baik pada ibu bapakmu dengan sebaikbaiknya. Jika salah seorang di antara keduanya atau kedua-duanya sampai berumur lanjut dalam pemeliharaanmu, maka sekali-kali janganlab kamu mengatakan kepada keduanya perkataan "ab" dan janganlah kamu membentak mereka dan ucapkanlah kepada mereka perkataan yang mulia." (QS. AlIsra' [17]: 23).

- O rang tua sebagai sarana mendapat Surga "Sungguh bina, sungguh bina, kemudian sungguh bina, orang yang mendapatkan salah seorang atau kedua orangtuanya lanjut usia di sisinya (semasa bidupnya), namun ia (orangtuanya) tidak memasukeannya ke Surga." (HR: Abmad).

"Ya Rasulullah aku ingin ikut perang dan aku datang kepadamu untuk meminta saran". Rasulullah pun bertanya, "Apakah kamu masih mempunyai ibu?" "Ya, masib," jawabnya. Maka beliau bersabda, "Kalau begitu, temanilah ia, karena surga itu terletak di kedua kakinya."

(HR. Ahmad).

- Pahala bersabar merawat orang tua dan orang sakit

Memang menjaga dan menunggu orang tua dan sakit memang butuh kesabaran ekstra, melayaninya, mengambilkan sesuatu, kurang tidur sampai mengurus ketika ia BAB dan BAK. I nisangat menguras tenaga dan banyak menghabiskan waktu.

Rasulullah Shallallahu 'alaibi Wa sallam bersabda,

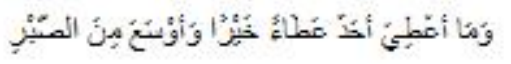

Tidaklah seseorang diberi pemberian yang lebih baik dan lebih luas daripada kesabaran." (HR. Al-Bukhari no. 1469 dan Muslim no. 2421)

- A malan Tergantung dari A khirnya

"Sesunggubnya salah seorang dari kalian benar-benar beramal dengan amalan abli surga, sehingga jarak antara dirinya dengan surga hanya satu hasta, lalu dia didahului oleh catatan takdirnya, sehingga dia beramal dengan amalan abli neraka, sehingga dia memasukinya. Dan salah seorang di antara kalian benar-benar beramal dengan amalan abli neraka, bingga jarak antara dirinya dengan neraka hanya sehasta, lalu dia didabului oleh catatan takdirnya, sehingga dia beramal dengan amalan abli surga bingga dia memasukinya." (HR Bukbari dan Muslim)

Ambulation and Transportation

Problematika (H annon K, 2015).

- Penurunan fungsi muskulo skeletal à hambatan interaksi sosial

- K esendirian, isolasi à penurunan fungsi kognitif, memori lebih cepat à demensia

- Resiko depresi yang meningkat

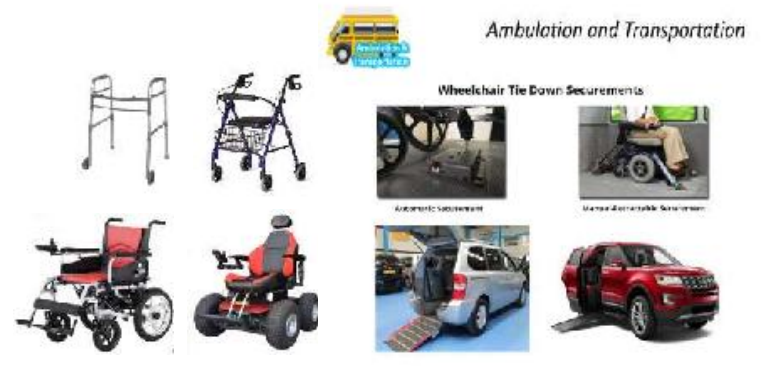

Gambar 7. Contoh Layanan Ambulation and Transportation pada Senior Center

Law and Advocation

Peran hukum dan advokasi

- Hukum dan advokasi akan membantu melindungi hak-hak orang yang tinggal dalam senior center, ataupun orang lanjut usia yang terdaftar agar mereka mendapatkan perlakuan secara adil.

- Membantu memberikan advokasi bagi lanjut usia yeng menjadi korban kekerasan (elder abuse).

- Membantu konsultasi terkait hukum-hukum terkait waris dan pembagiannya.

- Bekerja sama dengan komnas HAM perlindungan orang tua

- Membantu advokasi bantuan dana pensiun maupun bantuan sosial lansia

Help and Services (Sarosy L, 2009).

- Pemantauan kondisi rumah, keamanan

- Pemantauan dan pertolongan pertama lanjut usia dari resiko jatuh 
- Pemantauan kondisi rumah, keamanan, yang dapat diakses oleh:

- Pemilik rumah, sehingga tetap bisa dipantau saat bekerja dikantor, dll.

- Petugas keamanan (security) di layar pusat terkontrol.

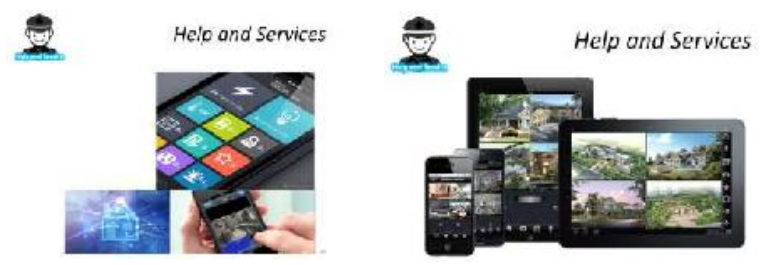

Gambar 8. Layanan Help and services berupa CCTV dan pemantauan kondisi keamanan warga lanjut usia.

- Pemberian gejang indikator fall risk
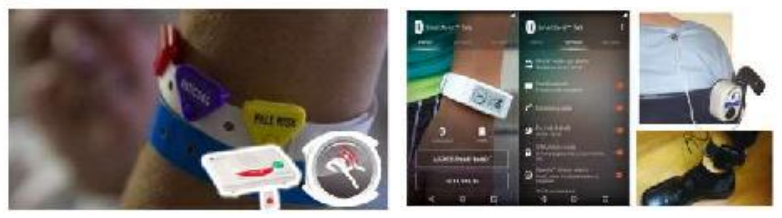

Gambar 9. Layanan gelang indikator fall risk dan modifikasi digital smartband warga lanjut usia

Playroom and Gym

Problematika lanjut usia

- Kesendirian, isolasi meningkatkan resiko dementia, depresi, insomnia, dll. pada usia lanjut. Solusi problematika lanjut usia

- K egiatan bersama dalam komunitas

- Evaluasi potensi diri dan kesukaan (bobby)

- Small and large discussion

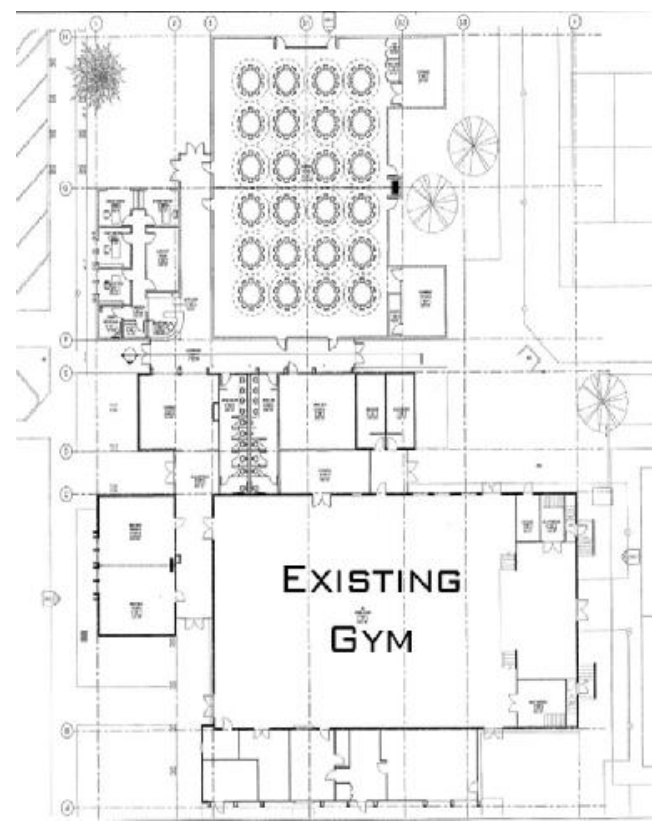

Gambar 10. Contoh Design Interior Playroom and Gym

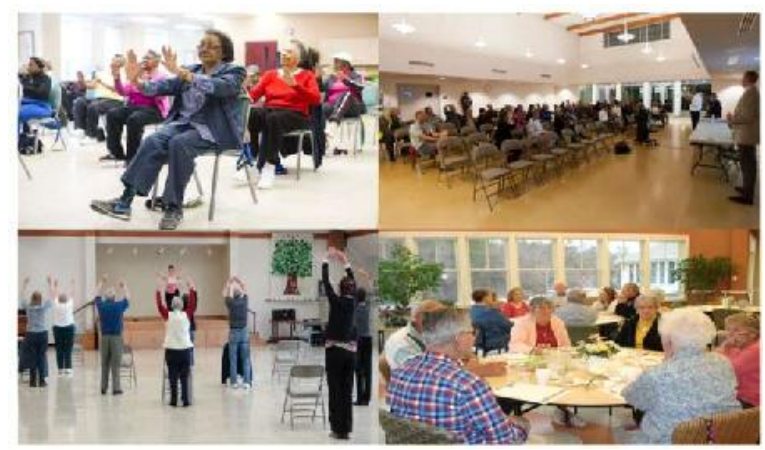

Gambar 11. Contoh Kegiatan Senior Center berupa Big Class Discussion and Small Round Class Discussion

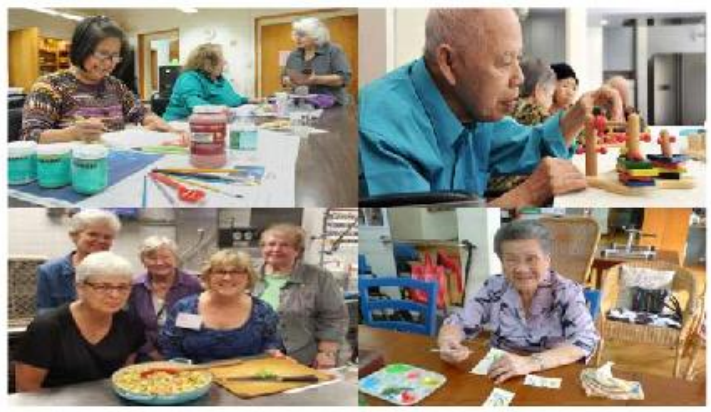

Gambar 12. Contoh Kegiatanmewarnai, cooking class, bermain pada lanjut usia 

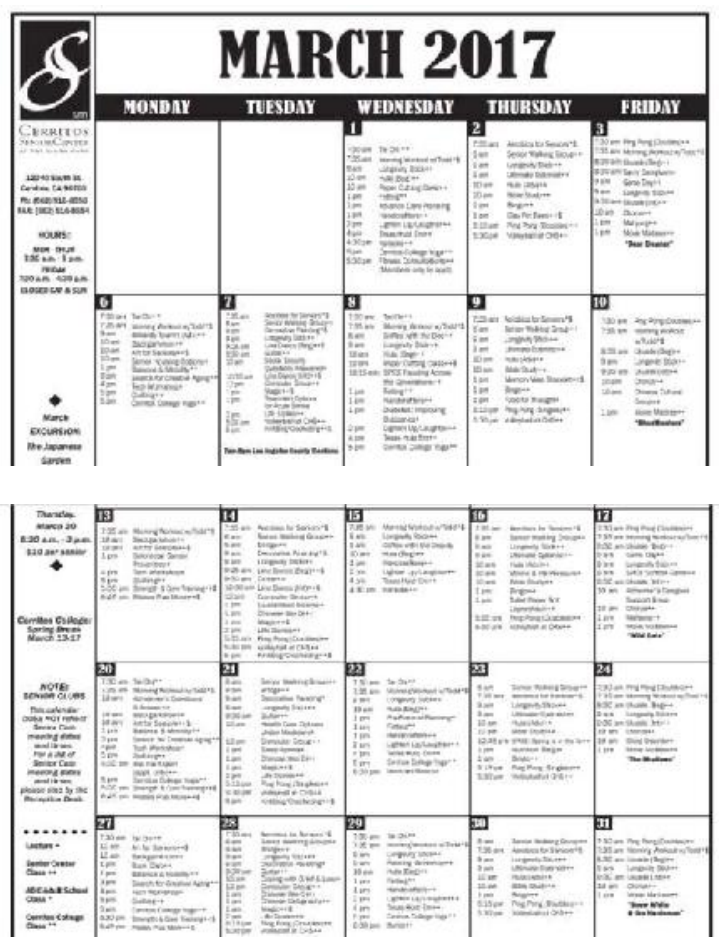

Gambar 13. Contoh Agenda Senior Center selama 1 bulan

\section{Smart Home}
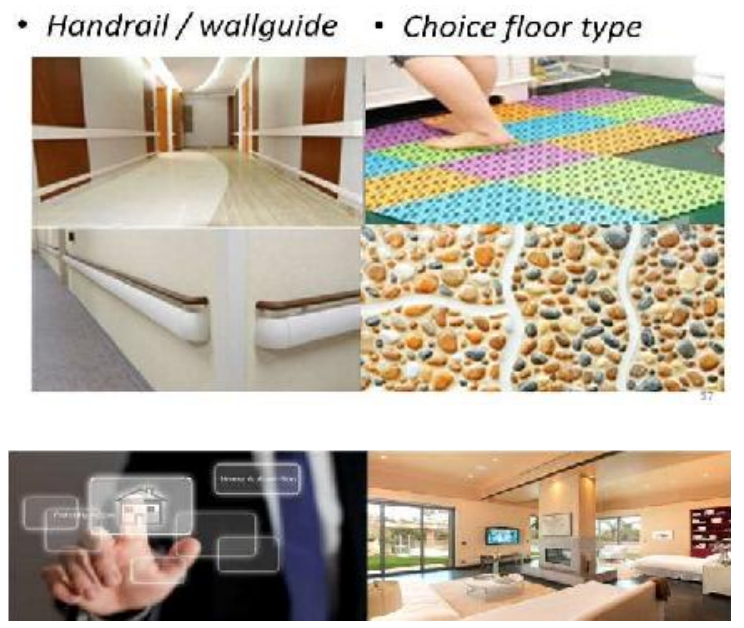

Gambar 14. Modifikasi Interior Smart Home, rumah ramah lanjut usia

\section{DISKUSI}

Peran Senior Center bagi Permasalaban Geriatri

Demensia

Sindroma penurunan fungsi kognitif secara global yang bersifat progresif yang mempengaruhi kesehatan individu dan fungsi sosialnya. Seseorang dengan demensia memiliki kesulitan belajar dan memori dengn salah satu berikut (Sunarti S, 2016):

- gangguan komunikasi (aphasia),

- memberikan alasan,

- merencanakan sesuatu (excecutive function),

- agnosia dan apraxia,

- orientasi dan regulasi emosi.

Manajemen Demensi dapat dilakukan dengan cara (Sunarti S, 2016):

- Melibatkan seorang usia lanjut pada kehidupan sosial yang lebih intensif serta partisipasi pada aktivitas yang merangsang fungsi kognitif dan stimulasi mental maupun emosional untuk menurunkan risiko penyakit Alzheimer dan memperlambat munculnya manifestasi klinis gangguan kognitif.

- untuk pasien, reminiscence, terapi musik, psikoterapi, modifikasi perilaku

- konsultasi untuk pramuwerdha, jaminan nutrisi yang optimal

- Latihan memori multifaset dan latihan relaksasi

- Penyampaian informasi yang benar kepada keluarga, latihan orientasi realitas

- rehabilitasi, dukungan kepada keluarga, manipulasi lingkungan, program harian

- Pemberian obat pada BPSD ditujukan untuk target gejala tertentu dengan pembatasanwaktu.

- Tentukan target gejala yang hendak diobati, identifikasi pencetusgejala; psikoterapi dan konseling diberikan bersama dengan obat (risperidon,sertralin, atau haloperidol, sesuai dengan gejala yang muncul)

\section{Depresi}

Penyakit mental paling sering pada pasien berusia di atas 60 tahun dan merupakan penyakit dengan tampilan gejala tidak spesifik pada populasi geriatri.

Faktor biologis, fisis, psikologis dan sosial yang membuat seorang berusia lanjut rentan terhadap depresi. Perubahan pada sistem saraf pusat seperti meningkatnya aktivitas monoamine oksidase dan berkurangnya konsentrasi neurotransmitter terutama katekolaminergik berperan dalam terjadinya depresi pada usia lanjut. Kondisi multipatologi, psikososial, dan polifarmasi 
juga berperan sebagai faktor predisposisi depresi (Sunarti S,2016).

Manajemen depresi, dapat dikategorikan menjadi :

D epresi ringan: Pemantauan rutin

D epresi sedang: Cognitive behavioural therapy

Depresi berat: Antidepressant golongan SSRI 1-2 tahun sampai remisi.

Kerapuban (frailty)

Penurunan cadangan dan kemampuan tubuh dalam menghadapi stressor, yang berakibat penurunan berbagai system fisiologis sehingga terjadi hasil yang jelek dan tingginya kematian.

$\mathrm{K}$ riteria Frailty berdasarkan Cardiovascular bealth study(Sunarti S, 2016)).

- Penurunan berat badan lebih dari $5 \mathrm{~kg}$ dalam 1 tahun terakhir atau penurunan berat badan $>5 \%$ selama pemantauan

- Kekuatan genggaman tangan menurun $20 \%$ dari nilai standar

- Kecepatan berjalan menurun $20 \%$

- Banyaknya kilo kalori dari aktivitas yang dilakukan per minggu yang telah disesuaikan dengan jenis kelamin

Bila memenuhi 1 atau 2 dikatakan Pre-frail dan bila lebih dari sama dengan 3 dikatakan frailty. Manajemen kerapuhan (frailty) (Sunarti S, 2016):

- D iet dengan kecukupan asupan protein, vitamin C, D, E dan mineral

- Latihan fisik yang teratur baik sendiri atau berkelompok

- Pemantauan rutin kemampuan dasar individu seperti kemampuan berjalan, keseimbangan, dan status kognisi

- Pemberian vaksinasi mencegah infeksi flu, radang paru, dan herpes zoster

- Rekondisi cepat setelah ada suatu kondisi stress melalui renutrisi dan fisioterapi

Insomnia

K eluhan orang tua dalam jangka lama dan biasanya ditandai ketidakmampuan memperoleh tidur yang adekuat, keluhan kesehatan ini merupakan permasalahan medis atau hanya kebiasaan (Sunarti S, 2016).
- Kesulitan tidur ini termasuk:

- sulit memulai tidur,

- sering terbangun, bangun terlalu pagi dan tidak bisa kembali tidur,

- bangun dengan kondisi tidak bugar.

- Mungkin juga didapatkan pasien mengatakan:

- nafasnya waktu malam tidak normal,

- merasa tidak nyaman, atau

- gerakan - gerakan yang mengganggu tidur.

Manajemen insomnia (Sunarti S, 2016)

- CBT secara khusus memberikan sleep education, relaxation techniques, cognitive restructuring

- Farmakologi : berhati - hati setelah diketahui sleep habits, maladaptive behaviors, dan komorbid penyebab gangguan tidurnya.

- Efek samping obat tidur termasuk perubahan kognitif, masalah psikomotor, dan hangover mengantuk siang hari, dapat sangat merugikan pada geriatrik.

Jatub (falls)

Perubahan posisi yang tidak disengaja yang menyebabkan seseorang terjatuh di tanah, lantai, atau tempat yang lebih rendah karena ketidak hatihatian dengan atau tanpa penurunan kesadaran (Sunarti S, 2016, Tantri N, et al 2014).

Proses menua mengakibatkan perubahan kontrol postural, postur tubuh, gaya berjalan, ayunan postural, sistem sensorik, dan mobilitas fungsional. Jatuh terjadi dimana system control postural tubuh gagal mendeteksi pergeseran dan tidak mereposisi pusat gravitasi terhadap landasan penopan pada waktu yang tepat untuk menghindari hilangnya keseimbangan ((Sunarti S, 2016, Tantri N, et al 2014).

Faktor resiko intrinsic ((Sunarti S, 2016, Tantri N, et al 2014):

- Lokal: O steoartritis genu/vertebrae lumbal, gangguan pendengaran, penglihatan, kelemahan otot quadrisep femoris, plantar fasciitis, vertigo

- Sistemik: PPOK, Pneumonia, IMA, Gagal jantung, ISK, demensia, diabetes mellitus atau hipertensi yang tidak terkontrol, gangguan aliran darah ke otak (CVA, TIA), Parkinson, atau gangguan metabolic seperti hiponatremia, hipoglikemia, hiperglikemia, hipoksia 
Faktor resiko ekstrinsik(Sunarti S, 2016, Tantri N, et al 2014):

- Faktor di lingkungan seperti: lantai licin dan lampu kurang terang, tangga yang tidak aman, bak kamar mandi terlalu tinggi atau rendah, kabel dan tali yang berserakan di lantai, karpet yang terlipat.

M anajemen jatuh (falls) (Sunarti S, 2016, Tantri N, et al 2014) :

- Identifikasi faktor resiko ekstrinsik dan intrinsic

- Perubahan lingkungan dengan menggunakan bed yang lebih rendah

- Latihan desensitisasi faal keseimbangan, latihan fisik dan adaptasi perilaku

- Mengobati keluhan visual

- Mengatasi hipotensi postural

- Menangani gangguan detak jantung dan irama jantung

- Edukasi keluarga

- Suplementasi vitamin D

- Terapi osteoporosis

- Home visit

Analisis Keleuatan dan Kelemaban Implementasi Senior Center di Indonesia

Kekuatan (Strength) (K emenkes RI, 2016).

a. Adanya komitmen global berdasarkan deklarasi Internasional Madrid 2002 (Madrid International Plan of Action on Ageing 2002)

b. Adanya komitmen nasional dalam memperhatikan kesejahteraan lanjut usia termasuk status kesehatan lanjut usia

c. Penetapan tanggal 29 Mei sebagai Hari Lanjut U sia $\mathrm{N}$ asional yang diperingati setiap tahun

d. Tersedianya sarana pelayanan kesehatan mulai dari puskesmas, rumah sakit kabupaten/kota dan rumah sakit provinsi di seluruh Indonesia

e. Adanya kebijakan dari beberapa pemerintah daerah yang memperhatikan masalah kesejahteraan lanjut usia.

f. A danya Rancangan Aksi Nasional untuk Kesehatan Lansia di Indonesia oleh $\mathrm{K}$ ementerian Kesehatan

g. Standar Nasional A kreditasi Rumah Sakit (SN ARS) edisi 1menharuskan semua Rumah Sakit memasukkan Program Pelayanan G eriatri sebagai Program Nasional di Rumah Sakit
Kelemahan (Weakness) (K emenkes, 2016).

a. Belum semua puskesmas dan rumah sakit memiliki tenaga terlatih pelayanan kesehatan santun lanjut usia

b. Belum semua puskesmas dan rumah sakit memiliki sarana dan prasarana pelayanan kesehatan santun lanjut usia

c. Belum semua puskesmas dan rumah sakit melaksanakan pelayanan berdasarkan konsep pelayanan kesehatan santun lanjut usia

d. Masih terbatasnya jumlah rumah sakit yang menyediakan pelayanan geriatric

e. Belum tersedianya penggolongan khusus untuk karakteristik lanjut usia pada Jaminan K esehatan $\mathrm{N}$ asional

f. Belum semua kabupaten/kota menggalang kemitraan dengan lintas sektor maupun dunia usaha termasuk dengan BUMN dan BUMD.

g. Belum optimalnya sistem pencatatan dan pelaporan pelayanan kesehatan lanjut usia

h. Kurangnya pengetahuan dan perhatian masyarakat terutama generasi muda terhadap permasalahan kesehatan lanjut usia.

i. Belum semua kabupaten/ kota melaksanakan pemberdayaan lansia bagi peningkatan kesehatan dan kesejahteraan keluarga dan masyarakat

j. K urangnya jumlah penelitian tentang kesehatan lanjut usia yang dilakukan oleh Perguruan Tinggi maupun Balitbang K ementerian K esehatan.

k. Belum optimalnya koordinasi lintas program dalam melakukan pembinaan kesehatan lanjut usia.

Peluang (Opportunity) (K emenkes, 2016).

a. Adanya peraturan perundang-undangan tentang kewenangan desa yang meliputi pembinaan kemasyarakatan desa dan pemberdayaan masyarakat

b. Adanya kewajiban perusahan untuk menyediakan dana Coorporate Social Responsibility sehingga dapat dimanfaatkan untuk mendukung kegiatan masyarakat termasuk kesehatan lanjut usia

c. A danya peraturan pemerintah tentang dana desa yang bersumber dari APBN

d. Adanya Komisi Nasional Lanjut Usia yang dibentuk berdasarkan K eputusan Presiden yang anggotanya berasal dari lintas sektor dan tokoh masyarakat. 
e. A danya Peraturan M enteri D alam N egeri tentang Pedoman Pembentukan Komisi D aerah Lanjut Usia dan Pemberdayaan Masyarakat dalam penanganan lanjut usia di daerah.

f. A danya indikator pelayanan kesehatan lansia di dalam standar pelayanan minimal bidang kesehatan di kabupaten/ kota.

g. Banyaknya organisasi profesi, LSM dan organisasi masyarakat yang terkait dengan lanjut usia.

h. Sebagian lanjut usia masih dalam kondisi sehat dan potensial untuk meningkatkan kesehatan diri dan keluarganya.

i. A danya pusat kajian kelanjutusiaan di beberapa perguruan tinggi.

j. A danya program kesehatan terkait lanjut usia diberbagai unit kerja di lingkungan $\mathrm{K}$ ementerian $K$ esehatan.

k. A danya program terkait lanjut usia pada lintas sektor terkait.

Tantangan (Threat)(K emenkes, 2016).

a. Belum semua K omisi $D$ aerah di tingkat provinsi berfungsi optimal.

b. Masih kurangnya komitmen sebagian besar pemerintah daerah dalam memperhatikan kesejahteraan lanjut usia

c. Bertambahnya jumlah Ianjut usia sebagai akibat dari meningkatnya $\mathrm{UHH}$, dapat menimbulkan permasalahan kesehatan yang berhubungan dengan penyakit degeneratif dan kesehatan reproduksi dan seksual

d. K ebutuhan pelayanan kesehatan untuk penyakit degeneratif memerlukan biaya tinggi.

e. A danya permasalahan kesehatan pada ibu hamil, bayi, anak dan dewasa, yang semuanya berdampak pada masa lanjut usia.

Kebijakan Pemerintah terhadapKesejabteraan Lanjut Usia K ebijakan pemerintah terhadap kesejahteraan Iansia, meliputi:

1. UU Kesejahteraan Lanjut Usia (UU No 13/ 1998) pasal 1 ayat 1 (11):

"Kesejabteraan adalah suatu tata kehidupan dan penghidupan sosial baik material maupun spiritual yang diliputi oleh rasa keselamatan, kesusilaan, dan ketenteraman labir batin yang memungkinkan bagi setiap warga negara untuk mengadakan pemenuhan kebutuhan jasmani, rohani, dan sosial yang sebaik- baiknya bagi diri, keluarga, serta masyarakat dengan menjunjung tinggi hak dan kewajiban asasi manusia sesuai dengan Pancasila."

2. UU K esejahteraan Lanjut Usia (UU No 13/ 1998) pasal 1 ayat 2, 3 dan 4(K emenkes, 2016): "Lanjut Usia adalah seseorang yang telah mencapai usia 60 (enam puluh) tahun keatas. Dan mereka dibagi kepada dua kategori yaitu lanjut usia potential (ayat 3) dan lanjut usia tidak potnsial (ayat 4). Lanjut Usia Potensial adalah lanjut usia yang masib mampu melakukan pekerjaan dan/atau kegiatan yang dapat menghasilkan barang dan/atau jasa. Sedangkan Lanjut Usia Tidak Potensial adalab lanjut usia yang tidak berdaya mencari nafkah sebingga bidupnya bergantung pada bantuan orang lain. "Selanjutnya pada ayat 9 disebutkan bahwa pemeliharaan taraf kesejabteraan sosial adalah upaya perlindungan dan pelayanan yang bersifat terus-menerus agar lanjut usia dapat mewujudkan dan menikmati taraf hidup yang wajar."

- Berdasarkan UU tentang K esejahteran Lanjut Usia itu, tampaknya yang terbanyak d Indonesia adalah Lansia tidak potensial. Sebab, berdasarkan pekerjaaan, hanyak sedikit penduduk I ndonesia yang tersalurkan di sector formal, sedangkan mayoritasnya adalah di sector informal yang tidak jelas jaminan sosial hidupnya.

- Melihat kecenderungan meningkatnya jumlah penduduk Lansia di atas, pemerintah perlu mendorong dan memfasilitasi masyarakat untuk menyelenggarakan usaha-usaha kesejahtraan sosial terutama bagi lansia tidak potensal.

\section{KESIMPULAN}

Senior center adalah salah satu wahana untuk lansia mempertahankan kehidupan agar tetap sehat, aktif dan produktif. K egiatan ini sebaiknya difasilitasi oleh Pemerintah sesuai dengan UndangUndang dengan peran serat lintas sector untuk kebersinambungannya

\section{DAFTAR PUSTAKA}

Elizabeth B,2013,The Importance of Socialization at Senior Living Communities, (online). http:/ / www.umh.org/ assisted-independent-livingblog/bid/271766/ The-I mportance- of- 
42 VOLUME 14 NOMOR 1 JUNI 2018

Socialization-at-Senior-Living-Communities. [accessed 8 Maret 2017].

Hannon K, 2015,W hy We Need To Get Rid Of Senior Centers. (O nline). https:/ / www.forbes.com/ sites/ nextavenue/ 2015/ 03/ 19/ why-we-need-to-get-rid-of-seniorcenters/ [accessed 8 Maret 2017].

Haryanto JT, 2015,Penduduk Lansia dan Bonus Demografi K edua. Kementerian K euangan Republik Indonesia. (O nline). http:// www.kemenkeu.go.id/ Artikel/ penduduklansia-dan-bonus-demografi-kedua. [accessed 8 Maret 2017].

H ermana, 2010, Penduduk Lanjut U sia di I ndonesia dan M asalah K esejahteraannya. K ementerian Sosial Republik Indonesia. (online).http:// www.kemsos.go.id/ [accessed 8 Maret 2017].

Jacobson E et al,2016,T he I mpact of Senior Centers and G eriatric H ealthcare Policy. Institute for public administration college of human services. University of dekaware. (O nline). http:/ / www.ipa.udel.edu/ healthpolicy/ srcenters[accessed $8 \mathrm{M}$ aret 2017].

Kementerian Kesehatan Republik Indonesia. Peraturan Menteri Kesehatan Republik Indonesia Nomor 25 Tahun 2016 Tentang Rencan A ksi N asional K esehatan L anjut U sia Tahun 2016-2019, 2016. (O nline). http:// kesga.kemkes.go.id/images/ pedoman/

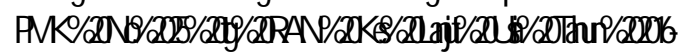
2019.pdf. [accessed 8 Maret 2017].

$\mathrm{K}$ ristina, 2009, Senior Centers:The Importance Elders Staying Active and Social. (O nline).http:/ / www.vickstromlaw.com/ 2009/ 10senior-centersthe-importance-eldersstaying-active-social/] [accessed $8 \mathrm{M}$ aret 2017].

Patton C,2012, Senior Socialization Leads to Better Quality of Life. (O nline). http:/ / www.aasc.org/ news/ articles/2011/ Sen

ior_Socialization_Leads_to_Better_Q uality_of_L ife.php [accessed $8 \mathrm{M}$ aret 2017].

Sarosy $L$,2009, The Important Role of Senior Centers to the Local Community. (online). http:/ / www.seniorcitizensguide.com/ articles/ philadelphia/ senior-centers.htm [accessed 8 Maret 2017].
Sunarti S, 2016, PPK G eriatri. Fakultas K edokteran Universitas Brawijaya, RS Saiful Anwar M alang. Indonesia.

Tantri N, et al, 2014,Sarkopenia, Larihan, dan K ejadian Jatuh (Falls) pada Populasi Lanjut Usia. Jurnal Kedokteran Brawijaya, 1, pp 35-39 